\title{
THE EFFECT OF SOLAR ENERGY ON THE ENVIRONMENTAL PROFILE OF ELECTRICITY GENERATION IN CHILE: A MIDTERM SCENARIO
}

\author{
MABEL I. VEGA ${ }^{1} \&$ CLAUDIO A. ZAROR ${ }^{2}$ \\ Department of Chemical Engineering, University of Concepcion-Chile
}

\begin{abstract}
The Atacama Desert in Northern Chile features the highest solar radiation on continental soil worldwide, ranging within 2,500-3,400 $\mathrm{kWh} / \mathrm{m}^{2} /$ year, with UV-B radiation levels $65 \%$ above average European. This desert covers an extension over $105,000 \mathrm{~km}^{2}$ receiving more than 4,000 hours of sunshine yearly, and hosts large reserves of copper, lithium, molybdenum and other metallic and non-metallic minerals. Thus, the Chilean mining industry accounts for more than $30 \%$ of the total electricity consumption in the country. During the last 3 years major investments on solar photovoltaic (PV) plants have taken place at the Atacama Desert, driven by the drastic drop in the cost of PV technology, and incentives provided by the new Energy 2050 Roadmap set by the Chilean government, with view to fostering the introduction of renewable energy sources in the electricity market. The Chilean electricity system is composed of two connected grids, namely the Greater Northern Network (SING) and the Central Network (SIC), with a total installed capacity of nearly $21 \mathrm{GW}$. The SING network is mostly composed of thermoelectric power plants, whereas the SIC network features a significant share of hydroelectric plants, leading to different carbon footprint, namely 0.9 and 0.3 ton $\mathrm{CO}_{2 \mathrm{eq}} / \mathrm{MWh}$, at SING and SIC, respectively. At the end of 2017, those grids were connected to meet the current $80 \mathrm{TWh} / \mathrm{year}$ national demand. Massive introduction of PV electricity generation plants at the Atacama Desert is foreseen in the near future, to reach a projected share around $25 \%$ by 2050. Within this framework, this paper presents novel results on the effect of solar energy on the environmental profile of electricity in Chile in a midterm scenario, using a life cycle assessment approach, under conditions of drastic reductions in water availability due to climate change. Results show that PV systems make a significant contribution to environmental impacts associated to electricity generation in the national mix by 2050, mainly in ozone layer depletion, abiotic depletion, global warming, acidification, and photochemical oxidation potentials impact categories, mainly from upstream transport and cell manufacturing. The extent of those impacts could increase significantly if the PV lifespan decreases due to cells degradation as a result of harsh environmental conditions, highlighting the need for reliable data on this key parameter. Keywords: Chile, electricity generation, life cycle assessment, solar PV technologies.
\end{abstract}

\section{INTRODUCTION}

Due to its outstanding solar potential, Chile has become a booming solar photovoltaic (PV) technology market, featuring an increase in PV electricity generation from less than $3 \mathrm{GWh} / \mathrm{y}$ to over 3,000 GWh/y in the last 4 years [1]. This trend is significantly higher than the fivefold increase in penetration velocity observed worldwide in the same period [2]. The share of PV generation in the Chilean matrix is expected to rise to nearly $25 \%$ within the next two decades, driven by the availability of high solar radiation, as well as the drastic reductions in investment costs, public incentives and appropriate electricity market conditions [3-6]. Interestingly, the Energy 2050 strategic roadmap established strategies to improve safety and quality of energy supply, environmental sustainability, and energy efficiency, among other key issues, fostering the introduction of renewable energy sources based on the unique solar, hydro, wind, and geothermal energy potential in Chile [6]. 
So far, most investments on PV and wind power plants have taken place at the Atacama Desert in Northern Chile, featuring the highest solar radiation on continental soil worldwide, ranging within 2,500-3,400 $\mathrm{kWh} \mathrm{m}^{-2} \mathrm{y}^{-1}$, with UV-B radiation levels $65 \%$ above average European radiation [3]. The Atacama Desert covers an extension over 105,000 km², receiving more than 4,000 hours of sunshine yearly.

Additionally, the Atacama Desert hosts large reserves of copper, lithium, molybdenum and other metallic and non-metallic minerals, and mining activities account for over $30 \%$ of total electricity consumption in Chile. Since electricity is an important input in mineral extraction and processing, e.g. 2-4 MWh/ton copper cathode, environmental burdens associated to electricity generation directly influence the environmental attributes of mineral products, and, as a consequence, their environmental competitiveness in an increasingly demanding market. Thus, mining operations are expected to benefit from those cleaner energy sources through direct electricity purchase from generators located nearby [7]. However, there is still some controversy on the environmental attributes of such cleaner energy sources, particularly in cases where impacts may occur in different parts of the life cycle. Indeed, PV electricity conversion processes features negligible environmental impacts since no fuels are used in electricity generation operations, except for panel maintenance. On the other hand, extraction and purification of raw materials are energy intensive processes, as well as photoelectric cell manufacturing, panel assembling, and end-of-life processes, leading to potential toxic exposure, water and air pollution, and resource depletion.

During the last decade, numerous PV life cycle assessment (LCA) have been conducted, in order to account for upstream and downstream environmental effects, with particular emphasis on energy related indicators and global warming potential, showing a wide dispersion in environmental impact results [8-16]. The environmental burdens associated to PV electricity generation depend on the type of PV technology, conversion efficiency, operating lifetime, capacity factor, solar radiation, panel manufacturing and end-of-life. The core of a PV plant is the solar cell converting the sun light into electricity by means of the PV effect, produced when radiation reaches a semiconductor unit presenting a potential gap. Currently, most operating PV systems are based on polycrystalline silicon, although some incipient penetration of cadmium-telluride (CdTe) and copper-indium-gallium-selenide (CIGS) has been recently observed [2].

Recently, there is growing concern that high radiation exposure, extreme weather conditions, and abrasive effect of sand dust could be a source of reduction in the efficiency and lifespan of solar PV panel, although the extent of those effects under real operating conditions are still under study [8]. In particular, the lifespan of electricity generation PV plants is a critical parameter to estimate the energy payback time, and annualized environmental loads for LCA purposes [9-11, 17]. Within this context, this paper reports a LCA study of PV electricity generation and its contribution to the environmental attributes of electricity generation in Chile under different mid-term scenarios, using primary data.

\section{METHODOLOGY}

The present work was developed following the ISO 14040:2006 [18] and ISO 14044:2006 [19] standards as the methodological framework to conduct this LCA study.

\subsection{Goal and scope definition}

The goal of this study was to assess the effect of the solar PV contribution to the environmental profile of electricity generation in Chile, projected to the year 2050. The electricity future 
scenario was chosen from the Energy 2050 Roadmap, considering a 25\% contribution from solar PV power plants by 2050 [6].

The system function is the generation of electricity and its delivery at point of connection to the electrical distribution system at the combined SING-SIC networks. The functional unit, which enables the system inputs/outputs to be quantified and normalized, is one kilowatt-hour (kWh electric) delivered at the busbar. This is a cradle-to-gate LCA study, and the system limits include all production steps from raw material extraction and purification, transport, equipment manufacturing and assembly, plant construction, maintenance and operation, and end-of-life. Electricity transmission and distribution are not included here.

\subsection{Environmental Impact Assessment Models}

There is a wide range of impact assessment models, involving mid-point and end-point approaches $[12,16]$. In this study, two models were used to cover mid and end point effects, namely, the updated version of CML 2 Baseline $2000 \mathrm{v} 2.05 /$ World, 1990 [20], and the Eco-indicator 99 Europe EI 99 H/A end-point impact assessment model. The former includes ten mid-point indicators that account for climate change, natural resources depletion, and environmental and toxicological impacts derived from emissions to soil, water, and air, among others. The latter considers three end-point indicators related to damage to human health, ecosystem quality, and resources usage, each related to a number of impact subcategories [21]. The software package Simapro ${ }^{\text {TM }}$ v.7.3.3 was used to model systems and calculate environmental impacts, on the basis of primary data complemented with the Ecoinvent database [22].

\subsection{Chilean Electricity Generation System}

The Chilean electricity generation system features a total installed capacity over $21 \mathrm{GW}$. The national network is composed of two grids that have recently connected, namely:

- The Northern grid (SING) extending $900 \mathrm{~km}$ from the city of Arica near the northern border with Peru (Latitude $18^{\circ} 28.476 \mathrm{~S}$ ) to Taltal (Latitude $25^{\circ} 24.5238 \mathrm{~S}$ ), accounting for around $24 \%$ of total national current installed generation capacity, mostly to supply mining and industrial activities.

- The Central-Southern grid (SIC) covering over 2,000 km length from Taltal to Chiloe (Latitude $43^{\circ} 7.0914$ S), serving $90 \%$ of Chilean population, and accounting for $76 \%$ of national installed generation capacity. No electrical energy is imported from neighboring countries or exported from Chile to them.

The SING is mostly composed of thermoelectric power plants, whereas the SIC features a significant share of hydroelectric plants, leading to different carbon footprint, namely 0.9 and 0.3 ton $\mathrm{CO}_{2 \mathrm{eq}} / \mathrm{MWh}$, at SING and SIC, respectively. At the end of 2017, those grids were connected to meet the current nearly $80 \mathrm{TWh} /$ year national demand.

\subsection{Electricity generation mid-term scenario 2017-2050}

Figure 1 illustrates the expected time evolution of the electricity generation mix in Chile, as defined by the Energy 2050 Roadmap [6], identifying contributing generation technologies. A significant increase in renewable energy sources could be observed, reaching nearly $90 \%$ 
contribution by 2050 . This scenario was used as the basis for the estimation of the environmental burdens associated to electricity generation over the period 2017-2050. According to this scenario, $\mathrm{PV}$ power generation is expected to meet additional electricity demand over the next seven years, whereas wind power technology is likely to make a greater contribution to meeting new electricity demand afterwards.

\subsection{Input/Output (I/O) data process from electricity generation in Chile}

The environmental profile of electricity generation in Chile for the period 1995-2010 was previously reported by the authors, including coal and natural gas power plants, wind power, biomass and hydroelectric generation [23, 24]. Those inventories have been used in the present study, complemented with PV electricity generation data.

The I/O data shown in Table 1, below, corresponds to values from a representative PV plant recently installed at SING, with 53 MW nominal generation capacity, based on polycrystalline silicon photoelectric cells. This inventory was used to estimate the environmental impacts of PV electricity generation, parametrized to $1 \mathrm{kWh}$ electricity.

Table 1: I/O process information for electricity generation from solar PV power plants.

\begin{tabular}{lll}
\hline I/O requirement & Unit & Amount \\
\hline Infrastructure stage. One 53MW PV power plant. & & \\
\hline Process water & $\mathrm{m}^{3} / \mathrm{plant}$ & $7.8910^{3}$ \\
Tap water & $\mathrm{m}^{3} / \mathrm{plant}$ & $8.8510^{3}$ \\
Fuel consumption (diesel) & $\mathrm{kg} / \mathrm{plant}$ & $40.8310^{3}$ \\
Cement & $\mathrm{m}^{3} / \mathrm{plant}$ & $1.8310^{3}$ \\
Gravel & $\mathrm{t} / \mathrm{plant}$ & $21210^{3}$ \\
Photovoltaic cell & $\mathrm{m}^{2} / \mathrm{plant}$ & $50410^{3}$ \\
Land occupation & $\mathrm{km} / \mathrm{plant}$ & 36 \\
Land transformation & $\mathrm{km}{ }^{2} \mathrm{y} / \mathrm{plant}$ & 1.44 \\
Glass & $\mathrm{t} / \mathrm{plant}$ & $3.4910^{3}$ \\
Transport, lorry & $\mathrm{t} \mathrm{km} / \mathrm{t}$ & $3.7910^{9}$ \\
Transport, transoceanic & $\mathrm{tkm} / \mathrm{t}$ & $8.8110^{7}$ \\
Recycling glass & $\mathrm{t} / \mathrm{plant}$ & $3.4910^{3}$ \\
Recycling non ferrous & $\mathrm{t} / \mathrm{plant}$ & $6.3110^{3}$ \\
Disposal inert material & $\mathrm{t} / \mathrm{plant}$ & $2.1410^{5}$ \\
\hline Electricity generation. Functional unit $1 \mathrm{kWh}$ & & \\
\hline Process water & & \\
Solar energy & $\mathrm{m} / \mathrm{kWh}$ & $4.8110^{-8}$ \\
Infrastructure & $\mathrm{kWh} / \mathrm{kWh}$ & 6.25 \\
Tap water & $\mathrm{p} / \mathrm{kWh}$ & $2.910^{-11}$ \\
Transport bus & $\mathrm{t} / \mathrm{kWh}$ & $2.7110^{-7}$ \\
Water, completely softened & $\mathrm{pkm} / \mathrm{kWh}$ & $8.7710^{-4}$ \\
Lubricating oil & ton $/ \mathrm{kWh}$ & $2.9510^{-6}$ \\
\hline & $\mathrm{kg} / \mathrm{kWh}$ & $4.5910^{-6}$ \\
\hline
\end{tabular}




\section{RESULTS AND DISCUSSION}

\subsection{Environmental profile of PV electricity generation}

In this study, the environmental profile was estimated on the basis of inventories obtained from PV plants installed in Chile, as shown in Table 1, above.

All PV plants currently installed in the country have declared a 25-27 years timespan; however, the harsh environmental conditions existing at the Atacama Desert have raised concern about possible reductions in conversion efficiency over time, leading to a decrease in operating lifespans. Therefore, environmental profiles were estimated for four lifespan scenarios, namely, 25, 20, 15 and 10 years, to assess the effect of lifespan reductions on environmental attributes of PV electricity generation.

Table 2 shows CML2000 mid-point and Ecoindicator 99 end-point environmental impacts associated to the generation of $1 \mathrm{kWh}$ as a function of lifespan. Significant increases in all impact categories could be observed as the PV plant lifespan decreases. Indeed, in all cases there is an inverse linear relationship between the plant lifespan and the environmental impact, with over $150 \%$ increase in impacts when lifespan decreases from 25 to 10 years. These results clearly highlight the need for more reliable data on PV plant lifespan. Since large scale PV plants are relatively new in Chile, the first one started operations at the end of 2012, further studies on the evolution of PV electricity conversion efficiency should provide greater clarity about this issue.

Table 2: Environmental profile associated to the PV generation of $1 \mathrm{kWh}$, as a function of lifespan for PV power plants in Chile.

\begin{tabular}{|c|c|c|c|c|c|}
\hline \multirow[t]{2}{*}{ Impact category } & \multirow[t]{2}{*}{ Unit } & \multicolumn{4}{|c|}{ Plant Lifespan } \\
\hline & & 25 years & 20 years & 15 years & 10 years \\
\hline \multicolumn{6}{|l|}{ CML 2000 mid-point impact categories } \\
\hline Abiotic depletion potential (ADP) & $\mathrm{kg} \mathrm{Sb}$ eq & $810^{-4}$ & $1010^{-4}$ & $1310^{-4}$ & $2010^{-4}$ \\
\hline Acidification (AC) & $\mathrm{kg} \mathrm{SO}_{2} \mathrm{eq}$ & $410^{-4}$ & $510^{-4}$ & $710^{-4}$ & $1010^{-4}$ \\
\hline Eutrophication (EPH) & $\mathrm{kg} \mathrm{PO}_{4} \mathrm{eq}^{-}$ & $110^{-4}$ & $110^{-4}$ & $210^{-4}$ & $310^{-4}$ \\
\hline Global warming (GWP) & $\mathrm{kg} \mathrm{CO}_{2} \mathrm{eq}$ & $110^{-1}$ & $110^{-1}$ & $210^{-1}$ & $310^{-1}$ \\
\hline Ozone layer depletion (ODP) & kg CFC-11 & $210^{-8}$ & $210^{-8}$ & $310^{-8}$ & $510^{-8}$ \\
\hline Human toxicity $(\mathrm{HT})$ & kg 1,4-DB & $310^{-2}$ & $410^{-2}$ & $510^{-2}$ & $810^{-2}$ \\
\hline Fresh water aquatic ecotox (FAET). & $\mathrm{kg} 1,4-\mathrm{DB}$ & $210^{-2}$ & $210^{-2}$ & $310^{-2}$ & $410^{-2}$ \\
\hline Marine aquatic ecotoxicity (MAET) & $\mathrm{kg} 1,4-\mathrm{DB}$ & 29 & 36 & 48 & 73 \\
\hline Terrestrial ecotoxicity (TET) & $\mathrm{kg} 1,4-\mathrm{DB}$ & $210^{-4}$ & $310^{-4}$ & $410^{-4}$ & $610^{-4}$ \\
\hline Photochemical oxidation (PO) & $\mathrm{kg} \mathrm{C}_{2} \mathrm{H}_{2}$ eq & $110^{-5}$ & $210^{-5}$ & $210^{-5}$ & $410^{-5}$ \\
\hline
\end{tabular}

Ecoindicator 99, end-point impact categories

\begin{tabular}{llllll}
\hline Human Health & DALY & $210^{-7}$ & $310^{-7}$ & $510^{-7}$ & $910^{-7}$ \\
Ecosystem Quality & PDF/m ${ }^{2} y$ & $710^{-2}$ & $910^{-2}$ & $210^{-1}$ & $310^{-1}$ \\
Resources & MJ surplus & $110^{-3}$ & $110^{-3}$ & $210^{-3}$ & $310^{-3}$ \\
\hline
\end{tabular}

Note: 1,4-DB: 1,4 dichlorobenzene equivalent; DALY: Disability-adjusted life years; PDF:

Potentially disappeared fraction. 
The GWP obtained here fall within the range of PV values reported in the literature ranging from 0.01 to $0.30 \mathrm{kgCO}_{2 \mathrm{eq}} / \mathrm{kWh}[2,9,12,15]$. Most studies show that transport of plant components from manufacturers to plant sites play a significant contribution to all environmental impacts categories. In the case of Chilean PV plants, the environmental burden associated to transport is quite significant since most manufacturers are located in China, involving a maritime distance of nearly $30,000 \mathrm{~km}$.

Additionally, manufacturing of PV equipment involves energy intensive processes, particularly in raw materials extraction and purification. Indeed, industrial production of silicon takes place by carbothermic reduction of silicon dioxide (quartz) in submerged-arc electric furnaces, featuring typical electricity consumption in the range 11-13 MWh/ton metallurgical grade silicon [25]. Molten multi-crystalline silicon is cast into ingots, and then into very thin wafers that are assembled into complete cells.

Transport is held responsible for 60-90\% of impacts in most categories, whereas PV cells manufacturing accounts for 10-20\% impacts, and end-of-life generates 10-25\% of human and ecotoxicity impacts (results not shown here due to space constraints).

In order to compare different impact categories associated to $1 \mathrm{kWh}$ PV electricity generation, normalization of environmental impact indicators was conducted. Normalized mid-point and end-point impacts are presented in Figs 2 and 3, respectively. As seen in Fig. 2, marine aquatic ecotoxicity (MAET) clearly dominates mid-point impacts, with minor contributions from fresh water aquatic ecotoxicity (FWAET) and abiotic depletion potential (ADP). On the other hand, as observed in Fig. 3, normalization of Ecoindicator-99 end-point categories show that the largest impact occurs on natural resources, followed by effects on human health; on the other hand, according to this model, impacts on ecosystem quality ranks much lower.

\subsection{Environmental profile of Chilean electricity mix scenario 2017-2050}

As seen in Fig. 1 below, electricity consumption is expected to grow by $150 \%$ over the next 3 decades. The electricity development strategy aims at reducing the share of fossil fuels contribution from its current $58 \%$ to less than $10 \%$ by 2050 .

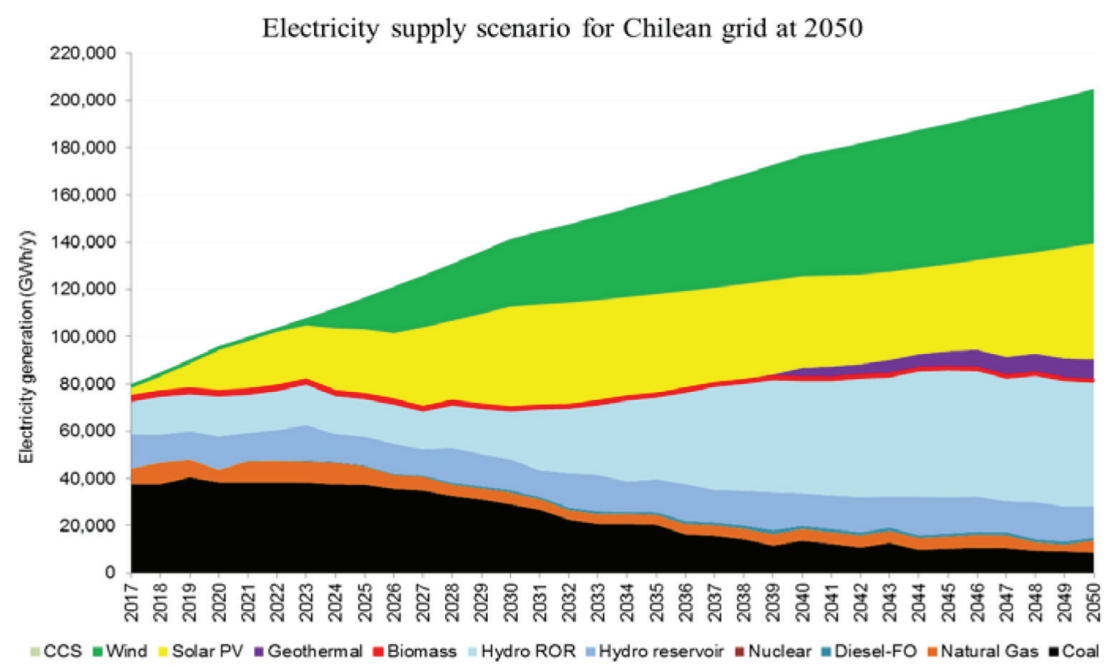

Figure 1: Projected electricity generation mid-term scenarios in Chile. 2017-2050 [6]. 


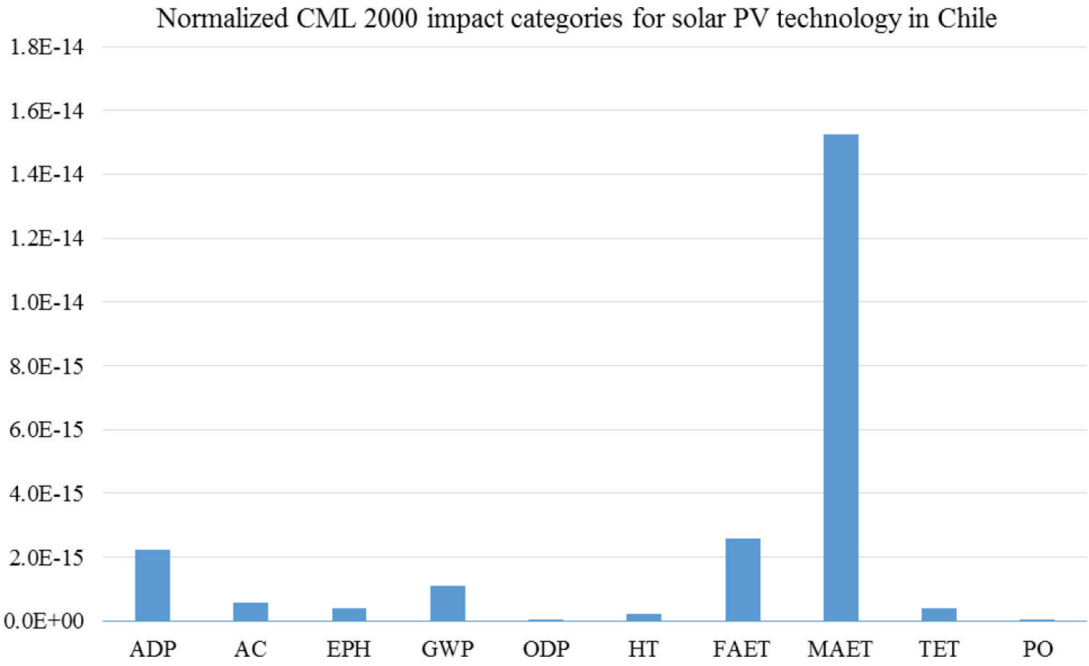

Figure 2: Normalized CML 2000/World 1990 mid-point environmental impact to produce $1 \mathrm{kWh}$ electricity from PV power plants in Chile.

Normalized Ecoindicator-99 impact categories for solar PV technology in Chile

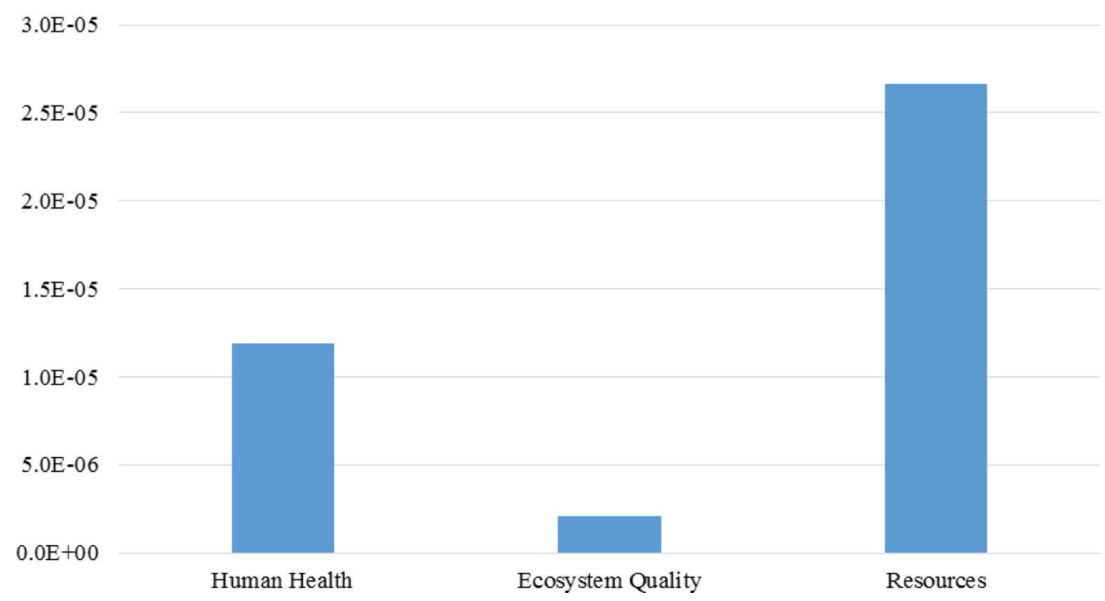

Figure 3: Normalized Ecoindicator-99 Europe EI 99 H/A end-point environmental impact to generate $1 \mathrm{kWh}$ electricity from PV power plants in Chile.

Electricity generation from coal- and natural gas-based thermoelectric plants steadily decreases from 2025, and new electricity demand is met by renewable sources.

Environmental attributes associated to the generation of $1 \mathrm{kWh}$ electricity by the SINGSIC mix are shown in Table 3 below, for the period 2020-2050, using the CML 2000 and Ecoindicator 99 impact models.

As seen in Table 3, all mid-point as well as end point impact categories experience significant reductions as a result of changes in the Chilean electricity matrix. Indeed, around $90 \%$ 
Table 3: Environmental attributes of $1 \mathrm{kWh}$ of electricity generated by the SING-SIC network. 2020-2050.

\begin{tabular}{|c|c|c|c|c|c|}
\hline \multirow{2}{*}{ Impact category } & \multirow[t]{2}{*}{ Unit } & \multicolumn{4}{|l|}{ Year } \\
\hline & & 2020 & 2030 & 2040 & 2050 \\
\hline \multicolumn{6}{|l|}{ CML 2000 mid-point impact categories } \\
\hline Abiotic depletion potential (ADP) & $\mathrm{kg} \mathrm{Sb}$ eq & $3010^{-4}$ & $2010^{-4}$ & $1010^{-4}$ & $710^{-4}$ \\
\hline Acidification (AC) & $\mathrm{kg} \mathrm{SO}_{2} \mathrm{eq}$ & $2010^{-4}$ & $1010^{-4}$ & $710^{-4}$ & $510^{-4}$ \\
\hline Eutrophication (EPH) & $\mathrm{kg} \mathrm{PO}_{4} \mathrm{eq}^{-}$ & $1010^{-2}$ & $610^{-2}$ & $210^{-2}$ & $110^{-2}$ \\
\hline Global warming (GWP) & $\mathrm{kg} \mathrm{CO}_{2}$ eq & $510^{-1}$ & $310^{-1}$ & $210^{-1}$ & $110^{-1}$ \\
\hline Ozone layer depletion (ODP) & $\mathrm{kg} \mathrm{CFC}-11$ & $910^{-9}$ & $1010^{-9}$ & $710^{-9}$ & $710^{-9}$ \\
\hline Human toxicity $(\mathrm{HT})$ & $\mathrm{kg} 1,4-\mathrm{DB}$ & 20 & 9 & 3 & 2 \\
\hline $\begin{array}{l}\text { Fresh water aquatic ecotoxicity } \\
\text { (FAET). }\end{array}$ & $\mathrm{kg} 1,4-\mathrm{DB}$ & 7 & 3 & 1 & 0.7 \\
\hline Marine aquatic ecotoxicity (MAET) & $\mathrm{kg} \mathrm{1,4-DB}$ & $7010^{2}$ & $4010^{2}$ & $1010^{2}$ & $810^{2}$ \\
\hline Terrestrial ecotoxicity (TET) & $\mathrm{kg} 1,4-\mathrm{DB}$ & $3010^{-3}$ & $1010^{-3}$ & $510^{-3}$ & $310^{-3}$ \\
\hline Photochemical oxidation (PO) & $\mathrm{kg} \mathrm{C}_{2} \mathrm{H}_{2}$ eq & $610^{-5}$ & $410^{-5}$ & $210^{-5}$ & $210^{-5}$ \\
\hline \multicolumn{6}{|c|}{ Ecoindicator-99 end-point impact categories } \\
\hline Human Health & DALY & $910^{-7}$ & $510^{-7}$ & $310^{-7}$ & $210^{-7}$ \\
\hline Ecosystem Quality & PDF $\mathrm{m}^{2} \mathrm{y}$ & $3010^{-2}$ & $2010^{-2}$ & $910^{-2}$ & $610^{-2}$ \\
\hline Resources & MJ surplus & $310^{-3}$ & $210^{-3}$ & $110^{-3}$ & $110^{-3}$ \\
\hline
\end{tabular}

reductions in human toxicity, ecotoxicity, and eutrophication potentials could be observed between 2020 and 2050. Moreover, global warming potential, acidification and abiotic depletion show $80 \%$ reductions for the same period, followed by a $75 \%$ decrease in photochemical oxidation potential, and only a $16 \%$ reduction ozone layer depletion. End point impacts also show important reductions, with around $80 \%$ for human health and ecosystem quality impacts, and $60 \%$ in resources depletion.

Figure 4 shows the contribution of generation technologies to each mid-point impact category corresponding to the year 2050 generation scenario. Although coal thermoelectric generation is expected to decrease significantly by 2050 , it appears to be the main contributor to marine aquatic ecotoxicity, fresh water aquatic ecotoxicity, terrestrial ecotoxicity and eutrophication. On the other hand, PV generation has a significant contribution to ozone layer depletion (55\% contribution), followed by lower effects on abiotic depletion potential (22\%), global warming (20\%), acidification (19\%), and photochemical oxidation $(18 \%)$.

Figures 5 and 6 show the time evolution of normalized mid-point and end-point impact categories, respectively, over the 2017-2050 period. In all cases, a significant decrease in environmental impacts could be observed, reflecting the drastic reduction in coal-based thermoelectric generation over that period. Marine aquatic ecotoxicity (MAET) is the largest comparative impact associated to the electricity generation in the SING-SIC mix, followed by fresh water aquatic ecotoxicity (FAET), and minor eutrophication effects (EPH). As far as 


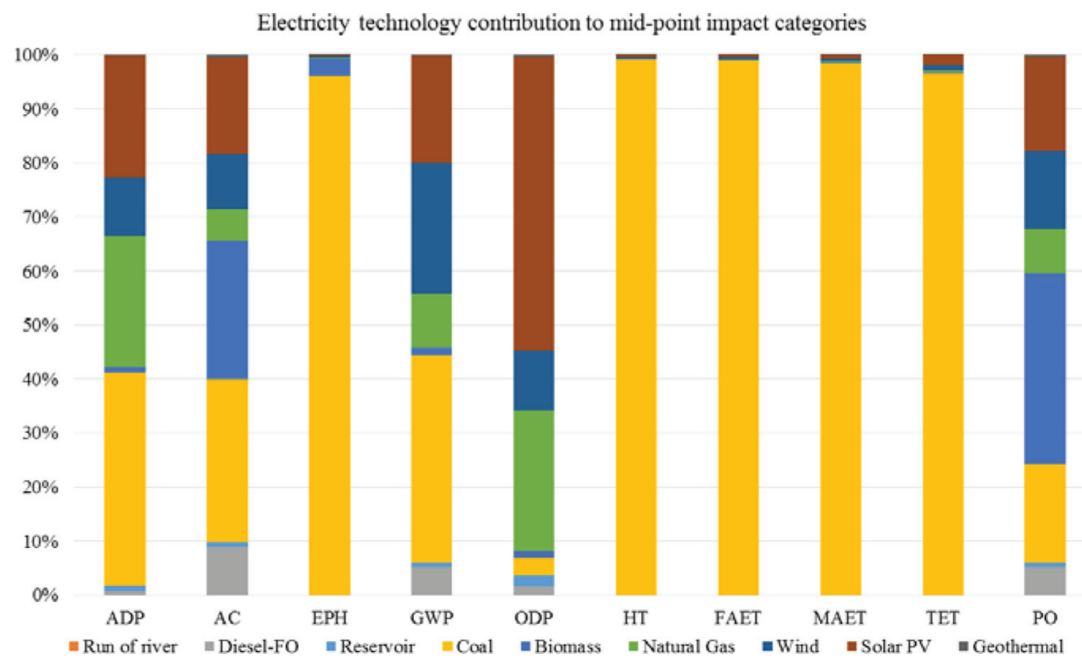

Figure 4: Environmental profile of electricity generation technology 2050. Mid point CML 2.0 impact model.

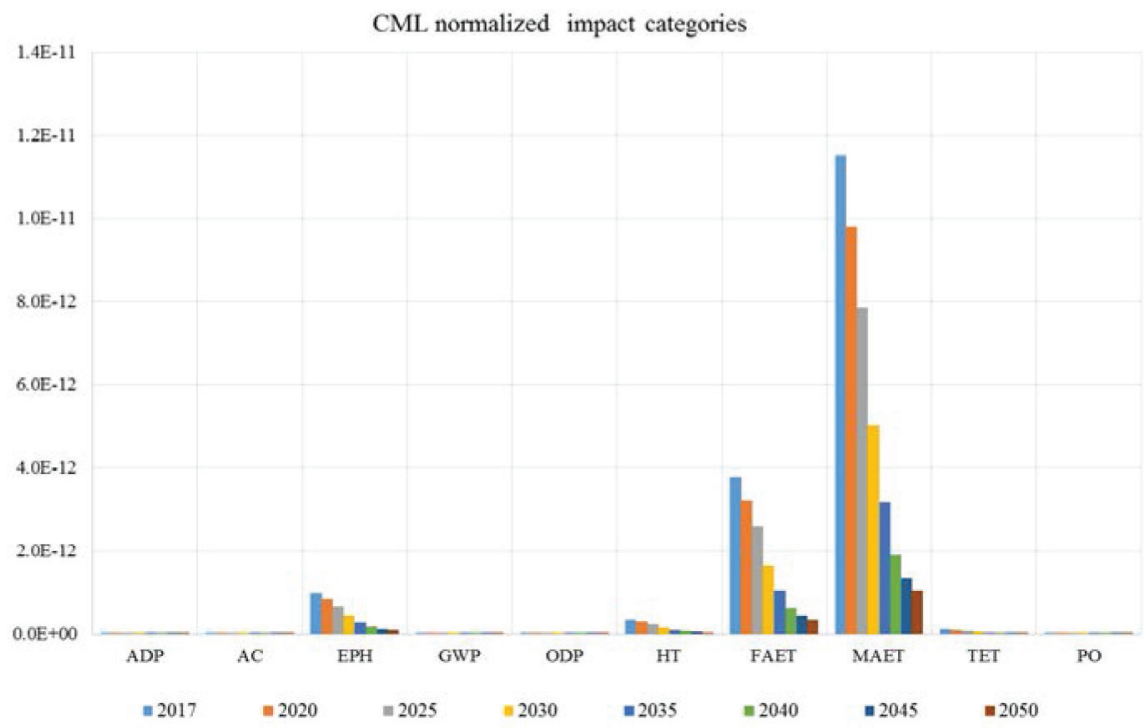

Figure 5: Normalized CML 2000 mid-point environmental impacts for electricity generation in Chile 2017-2050.

end-point impacts are concerned, respiratory organics, ecotoxicity and fossil fuels consumption are the main health and environmental impacts, in that order. Carcinogenic emissions, climate change, and land use appear as minor impact categories. All these impact categories are closely related to coal-based electricity generation. 


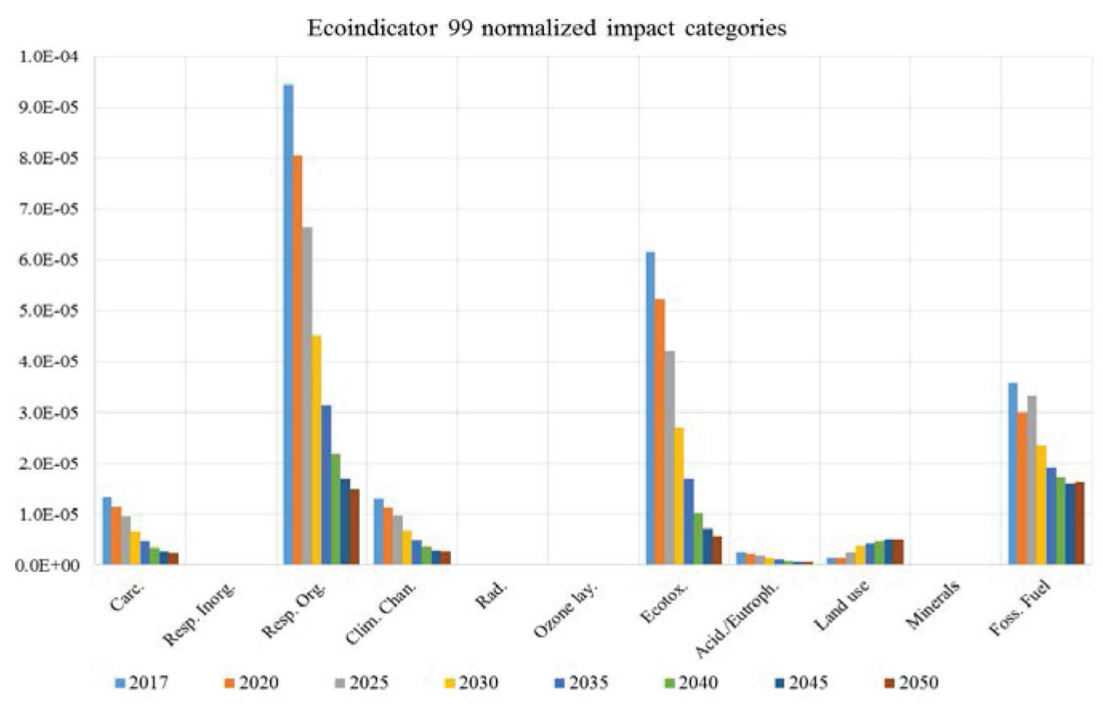

Figure 6: Normalized Ecoindicator-99 end-point environmental impact categories for Chilean electricity 2017-2050.

\section{CONCLUSIONS}

Chile features one of the fastest rates of PV penetration worldwide, in a context of high profitability despite the lack of subsidies or other financial governmental supports.

Results show that materials transport, PV equipment manufacturing, and lifespan of PV systems have an important effect on all mid-point and end-point environmental impact categories, with significant increases as the electricity generation efficiency decreases due to degradation of PV capacity. This is a key issue that need to be addressed as new evidence on such problem arises from practical experience under the harsh environmental conditions of the Atacama Desert.

Mid-term electricity generation scenario, as dictated by the Energy 2050 Roadmap, aims at minimizing the share of fossil fuels contribution to electricity generation, at the expense of greater penetration of $\mathrm{PV}$, wind and hydroelectric power plants. Sharp reductions shown in al impact categories over the 2020-2050 period are a direct consequence of fossil fuels replacement by renewable sources for electricity generation.

The $25 \%$ share of PV electricity generation in the national mix by 2050 , contributes with $55 \%$ of ozone layer depletion, $22 \%$ abiotic depletion, $20 \%$ global warming, $19 \%$ acidification, and $18 \%$ photochemical oxidation potentials associated to the national mix.

Results reported here should be regarded as a first approximation to assessing the environmental attributes of PV electricity generation, with view to decision-making.

\section{REFERENCES}

[1] Chilean Electricity Coordinator. Renewable energies annual report 2017, available at https://www.coordinador.cl/informe-documento/mercados/balance-ernc/balanceanual/ (accessed 03 January 2018).

[2] UNEP. Green Energy Choices: The benefits, risks and trade-offs of low-carbon technologies for electricity production. Report of the International Resource Panel. 
United Nations Environmental Program, eds. E.G. Hertwich, J. Aloisi de Larderel, A. Arvesen, P. Bayer, J. Bergesen, E. Bouman, T. Gibon, G. Heath, C. Peña, P. Purohit, A. Ramirez, \& S. Suh, UNEP: Paris, 2016.

[3] Bustos, C., Watts, D. \& Ayala, M., Financial risk reduction in photovoltaic projects through ocean-atmospheric oscillations modeling. Renewable and Sustainable Energy Reviews, 74, pp. 548-568, 2017. https://doi.org/10.1016/j.rser.2016.11.034

[4] Mints, P., Demand shift impacts pricing. Renewable Energy Focus, 15(4), pp. 14-15, 2014. https://doi.org/10.1016/s1755-0084(14)70090-0

[5] Pillai, U., Drivers of cost reduction in solar photovoltaics, Energy Economics, 50, pp. 286-293, 2015. https://doi.org/10.1016/j.eneco.2015.05.015

[6] Roadmap 2050, Advisory Committee-Energy 2050. Chilean Ministry of Energy, available at http://www.energia.gob.cl/sites/default/files/hoja_de_ruta_cc_e2050.pdf, September 2015.

[7] Moreno-Leiva, S., Díaz-Ferrán, G., Haas, J., Telsnig, T., Díaz-Alvarado, F. A., PalmaBehnke, R. \& Eltrop, L., Towards solar power supply for copper production in Chile: assessment of global warming potential using a life-cycle approach. Journal of Cleaner Production, 164, pp. 242-249, 2017. https://doi.org/10.1016/j.jclepro.2017.06.038

[8] De Simon-Martin, M., Diez-Mediavilla, M. \& Alonso-Tristan, C., Real energy payback time and carbon footprint of a GCPVS. Aims Energy, 5(1), pp. 77-95, 2017. https://doi. org/10.3934/energy.2017.1.77

[9] Stoppato, A., Life cycle assessment of photovoltaic electricity generation. Energy, 33(2), pp. 224-232, 2008. https://doi.org/10.1016/j.energy.2007.11.012

[10] Tsang, M. P., Sonnemann, G. \&, Bassani, D., A comparative human health, ecotoxicity, and product environmental assessment on the production of organic and silicon solar cells. Progress in Photovoltaics, 24, pp. 645-655, 2015. https://doi.org/10.1002/ pip. 2704

[11] De Wild-Scholten, M.J., Energy payback time and carbon footprint of commercial photovoltaic systems. Solar Energy Materials and Solar Cells, 119, pp. 296-305, 2013. https://doi.org/10.1016/j.solmat.2013.08.037

[12] Amponsah, N.Y., Troldborg, M., Kington, B., Aalders, I. \& Hough, R.L., Greenhouse gas emissions from renewable energy sources: a review of lifecycle considerations. Renewable and Sustainable Energy Reviews, 39, pp. 461-475, 2014. https://doi. org/10.1016/j.rser.2014.07.087

[13] Bergesen, J.D., Heath, G.A., Gibon, T. \& Suh, S., Thin-film photovoltaic power generation offers decreasing greenhouse gas emissions and increasing environmental co- benefits in the long term. Environmental Science \& Technology, 48(16), pp. 9834-9843, 2014. https://doi.org/10.1021/es405539z

[14] Berrill, P., Arvesen, A., Scholz, Y., Gils, H.C., \& Hertwich, E.G., Environmental impacts of high penetration renewable energy scenarios for Europe. Environmental Research Letters, 11(1), p. 14012, 2016. https://doi.org/10.1088/1748-9326/11/1/014012

[15] Masanet, E., Chang, Y., Gopal, A.R., Larsen, P., Morrow III, W.R., Sathre, R. \& Zhai, P., Life-cycle assessment of electric power systems. Annual Review of Environment and Resources, 38(38), pp. 107-136, 2013. https://doi.org/10.1146/annurev-environ-010710-100408

[16] Gerbinet, S., Belboom, S. \& Léonard, A., Life Cycle Analysis (LCA) of photovoltaic panels: a review. Renewable and Sustainable Energy Reviews, 38, pp. 747-753, 2014. https://doi.org/10.1016/j.rser.2014.07.043 
[17] Bhandari, K.P., Collier, J.M., Ellingson, R.J. \& Apul, D.S., Energy payback time (EPBT) and energy return on energy invested (EROI) of solar photovoltaic systems: a systematic review and meta-analysis. Renewable and Sustainable Energy Reviews, 47, pp. 133-141, 2015. https://doi.org/10.1016/j.rser.2015.02.057

[18] ISO 14.040:2006, Environmental Management- Life Cycle Assessment - Principles and Framework - International Standard ISO 14.040, 2006.

[19] ISO 14.044: 2006, Environmental Management- Life Cycle Assessment - Requirements and guidelines. International Standard ISO 14.044, 2006.

[20] Guinée, J.B., Gorrée, M., Heijungs, R., Huppes, G., Kleijn, R., de Koning, A., van Oers, L., Sleeswijk, A.W., Suh, S., Udo de Haes, H.A., de Bruijn, H., van Duin, R. \& Huijbregts, M.A.J., Handbook on life cycle assessment. Operational guide to the ISO standards. Kluwer Academic Publishers, Dordrecht, 2002.

[21] PRé Consultants. SimaPro 7.3.3. Pré Consultants, Amersfoort, the Netherlands, available at http://www.pre-sustainability.com/simapro-lca-software, 2009.

[22] Ecoinvent 3.4, Ecoinvent, available at https://www.ecoinvent.org/database/database. html, 2017.

[23] Vega, M. \& Zaror, C.A., Life cycle Inventory of electricity generation and distribution in Chile. Universidad de Concepción, Chile. Copyright N 241.457, 2011.

[24] Life Cycle Inventory of Electricity Generation in Chile. Presented at the International Conference on Life Cycle Assessment, CILCA, Coatzacoalcos, México, 2011.

[25] Xakalashe, B.S., Norway, T. \& Tangstad, M., Silicon processing: from quartz to crystalline silicon solar cells. Southern African Pyrometallurgy, eds. R.T. Jones, \& P. Den Hoed, Southern African Institute of Mining and Metallurgy, Johannesburg, 2011. 